\title{
PUBLIC OPINION ABOUT ENVIRONMENTAL POLLUTION
}

\author{
PhD Fatmir Emurllai \\ Faculty of Contemporary Science and Technologies, \\ South East European University, \\ Tetovo, Republik of North Macedonia \\ Institut for Environment and Health \\ E-mail: Fe26925@seeu.edu.mk
}

\begin{abstract}
The industrialized society now understands that one of the most necessary investments represents the protection of the environment, they have also realized that for the created state the main culprit is the man himself, by not keeping proper account of the nature that surrounds it. Air pollution and care for the environment during the years is a primary concern of many national and international institutions. Retention in this regard is part of the lives of citizens of these countries. Unfortunately, there is a lack of constructive awareness in less developed countries where the Republic of Northern Macedonia also participates. Some cities in this small country face enormous environmental pollution. In those settings, the municipality of Tetovo is also a preoccupation of this research.
\end{abstract}

Keywords: environmental protection, pollution, correct attitude towards nature, undertaking the measures by the relevant institutions.

\section{INTRODUCTION}

The protection of the living environment becomes ever greater demand for the survival of human civilization. There is also a need for mobilization of all human resources in terms of capacity building for the effective implementation of leading policy with the environmental life protection. It is clear that one of the main reasons for the degradation of the living environment is the inappropriate way of human behavior, as well as insufficient education for rational use of available resources. We can rightly say that today education represents the core strategy of governments, UN, international organizations and local non-governmental groups in the protection of the living environment. ${ }^{1}$

The right to a healthy living environment is a universal human right, as well as an individual right, but at the same time a collective obligation for all citizens to save themselves to preserve the environment. ${ }^{2}$ 
ISSN 2661-2666( Online) International Scientific Journal “Monte" DOI : $\underline{10.33807 / \text { monte.2.201908439 }}$ ISSN 2661-264X (Print)

Health protection consists of measures, activities and procedures for maintaining and the advancement of health, the living environment and the working environment, the rights and obligations that are realized in the health insurance, as well as masses, activities and procedures taken by organizations in the field of health for maintaining and advancing people's health, prevention and extinguishing of diseases, damage and other health deteriorations, early detection of diseases and health conditions, early and efficient medication and rehabilitation with the application of professional medical measures, activities and procedures. ${ }^{3}$

In a new report published for the Paris Conference on Climate Change by EEA in Copenhagen, it is estimated that 430,000 premature deaths per year in Europe are related to air pollution. Air pollution continues to harm the overall health of people and reduces the quality of life and life expectancy. This also has a significant impact on increasing medical care costs and because of job shortages for health reasons it also reduces the productivity of the entire economy. ${ }^{4}$

Air pollution is one of the most serious problems in the world. It has to do with the introduction into the atmosphere of polluting substances that affect people's health and the environment. The atmosphere is one of the most important ways of distributing polluting substances to the environment. The distance to the transport of polluting substances to the atmosphere may be several hundred to thousands of kilometers. This causes atmospheric pollution often have a regional character even global character. These pollutants are emitted from various sources and some of them act among them to form new compounds in the air. When we consider that, heavy metals are elements that can not be broken down, then these metals will continue to stay in the environment. Unlike many organic pollutants that eventually degrade in carbon dioxide and water, heavy metals will tend to accumulate in the environment, especially in lakes, at the estuary or in marine sediments. These metals can be transported from one part of the environment to the other. Downloads from heavy metals to the environment are a global problem, because they are an ever-increasing threat to the environment in general. ${ }^{5}$

\footnotetext{
${ }^{1}$ Ismaili, M, Durmishi, B (2006) : Shoqeria dhe menaxhimi I mbrojtjes se mjedisit, Tetove

${ }^{2}$ Kushtetuta e Republikes se Maqedonise, neni 43

${ }^{3}$ sluzben vesnik na R.M, zakon za zdravstvena zastita, osnovni odredbi, clen 1

${ }^{4}$ https://portalb.mk/222101-ndotja-e-ajrit-shkakton-vdekje-te-parakohshme/

${ }^{5}$ https://www.slideshare.net/ervisicara/projekt-ndotja-e-mjedisit-ervis-cara
} 
ISSN 2661-2666( Online) International Scientific Journal “Monte" DOI : $\underline{10.33807 / \text { monte.2.201908439 }}$ ISSN 2661-264X (Print)

The main sources of emissions of polluting substances are particularly metallurgical factories and plants, mines, combustion by-products, industrial releases, agricultural and urban development, pesticides containing heavy metals and traffic.

Ecological education is an active developmental process of learning in which individuals and groups benefit from much needed knowledge, meaning and skill for solving action, motivated, responsible and above all else in terms of achieving and maintaining dynamic equilibrium in the living environment. ${ }^{6}$

At the time of activities that could have an impact on the quality of ambient air, each is obliged to behave carefully and responsibility to avoid and prevent the pollution of environmental air and the harmful effects on health and the environment in general. ${ }^{7}$

Viewed from the above-mentioned perspectives the ongoing analysis has to do with one of the most polluted environments on the planet earth. It is about the city of Tetovo, located in the northwest part of the Republic of North Macedonia. In this research a considerable number of Tetovo population were surveyed mainly of young age, of different sexes and nationalities.

Of the respondents, 167 men and 153 women participated, expressed in percentage of 52\% male and $48 \%$ females. Of the above mentioned number 148 are aged $15-16$ years while $17217-18 \mathrm{yr}$. In this research, there are participants of 197 people living around the city of Tetovo (rural areas), and 123 in the city. Viewed by ethnicity, 160 are Albanians, 90 Macedonians, 50 Turks, 20 others. Of this number, 148 were first-year students and 172 of the fourth year. In the following we will highlight only some of the most interesting questions of this research.

\footnotetext{
${ }^{6}$ Srbinovski, M. (2005), Environmental education, Prosvetno delo, Skopje

${ }^{7}$ Sluzben vesnik na R.M, Zakon za kvalitet na ambientalniot vozduh,
} 
ISSN 2661-2666( Online) International Scientific Journal “Monte" DOI : 10.33807/monte.2.201908439 ISSN 2661-264X (Print)

Degree for researching your attitudes for assessment of the living environment

1. Very fast Earth will be overcrowded

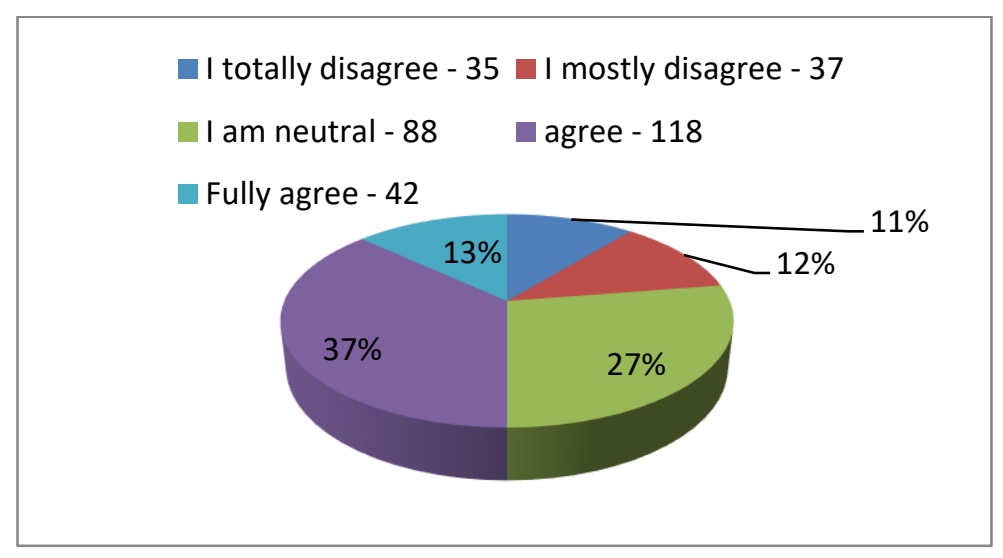

It is worrying that the question posed is noticed a lack of knowledge of high school youth about a vital problem for the future of the planet earth. This is evidenced by the fact that the 88 respondents expressed their neutrality.

\section{Human beings have the right to adapt their living environment to their needs .}

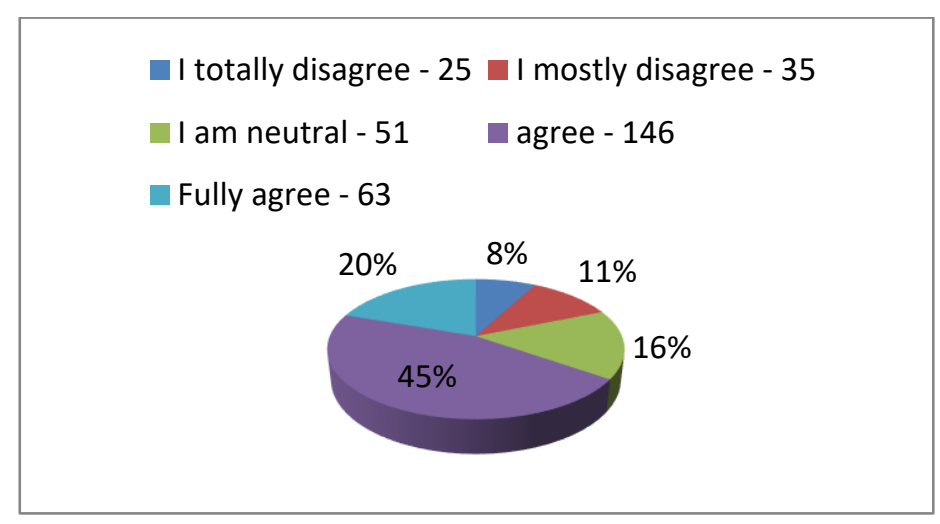

Failure to provide information even further comes to the answers given by the second question, where only 25 of the respondents expressed their position that they do not at all agree that human beings have the right to the living environment to adapt to their needs.

Still worrisome is the number of those who agree, respectively, fully agree that a person has the right to dispose of the environment according to needs and desires. 
ISSN 2661-2666( Online) International Scientific Journal “Monte" DOI : 10.33807/monte.2.201908439 ISSN 2661-264X (Print)

\section{When a person harasses nature, often faces dire consequences.}

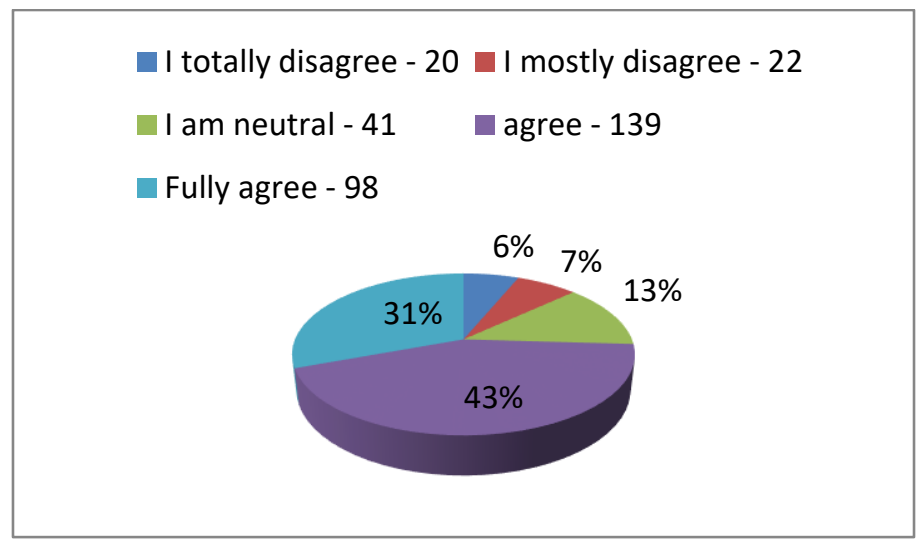

The answers to the third question are surprising, where 139 respondents agree that man often faces with terrible consequences in cases of harassing nature. If this is added to 98 respondents that completely agree, then everything becomes clearer. If we focus on the answers from the third question then we can conclude that maybe the preliminary questions were not sufficiently clear for the surveyed age groups and they have given not adequate answers to those questions.

\section{Human beings greatly misuse the natural environment.}

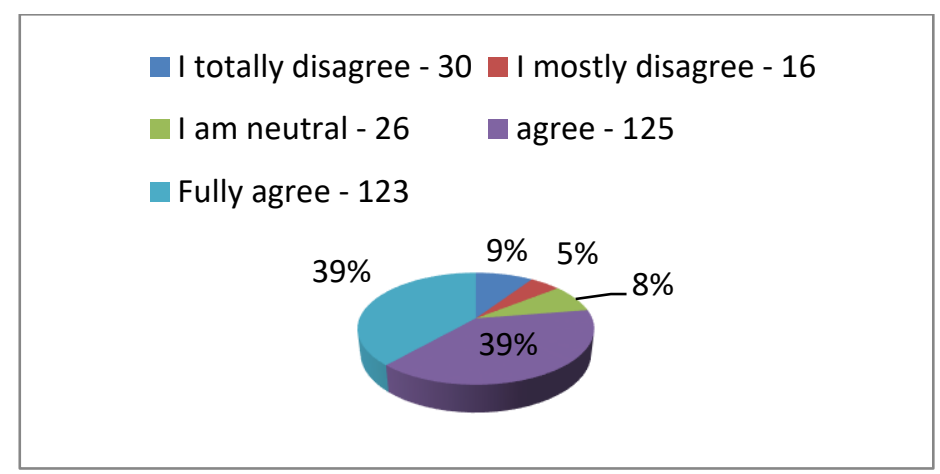

The fourth question even more confirms our assumption due to the fact that in these questions 125 respondents claim that human beings abuse the environment, while 123 others fully agree 
ISSN 2661-2666( Online) International Scientific Journal “Monte" DOI : 10.33807/monte.2.201908439 ISSN 2661-264X (Print)

\section{The plant and animal world have the same right to life as humans}

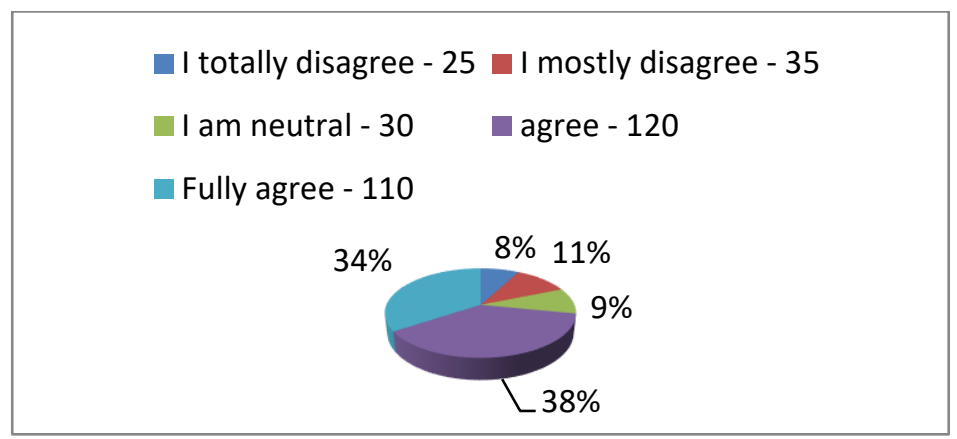

We are surprised by the fact that youth logic much more fairly than the older age groups for some fundamental issues related to the preservation of the environment. This is also evidenced by the answers given from the next question where 230 respondents agree or fully agree that the plant and animal world have the same right to life with humans.

\section{Nature is strong enough to eliminate harmful effects caused by developed countries}

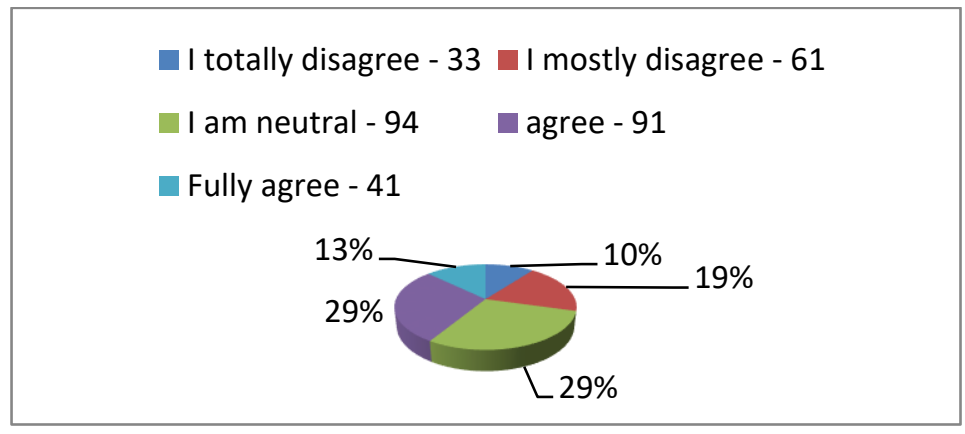

The next question to a significant extent reflects failure to properly inform the youth of Tetovo regarding industrial development. They did not do a better analysis, but have responded that nature is the one that in itself creates balance, bypassing the fact that traditionally developed countries have been the biggest environmental polluters. But this is not a rule, because many exceptions can be counted e.g the Republic of North Macedonia does not participate in developed industrial countries but is one of the most polluted sites in the globe. But because of the objectivity of these analyzes every time we have to consider the geographic extent of a state and the number of people living there. 
ISSN 2661-2666( Online) International Scientific Journal “Monte" DOI : 10.33807/monte.2.201908439 ISSN 2661-264X (Print)

7. Despite the great capabilities, as human being, we must nevertheless subject ourselves to the laws of nature

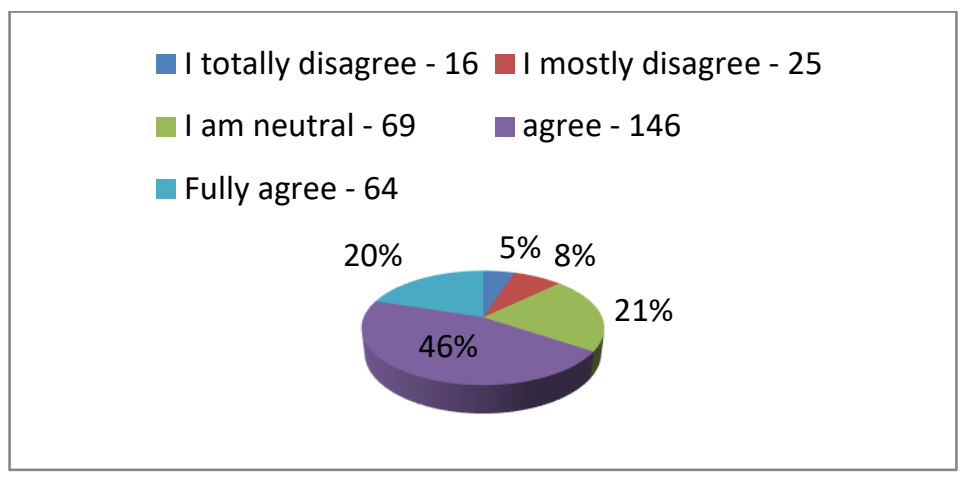

The next question again expresses a sound logic of the Tetovo high school youth, with the fact that 210 respondents have been expressed that apart from all achievements, human being must respect the laws of nature.

\section{The so-called statement „ecological crisis" that is threatened to the human race is exaggerated (excessive)}

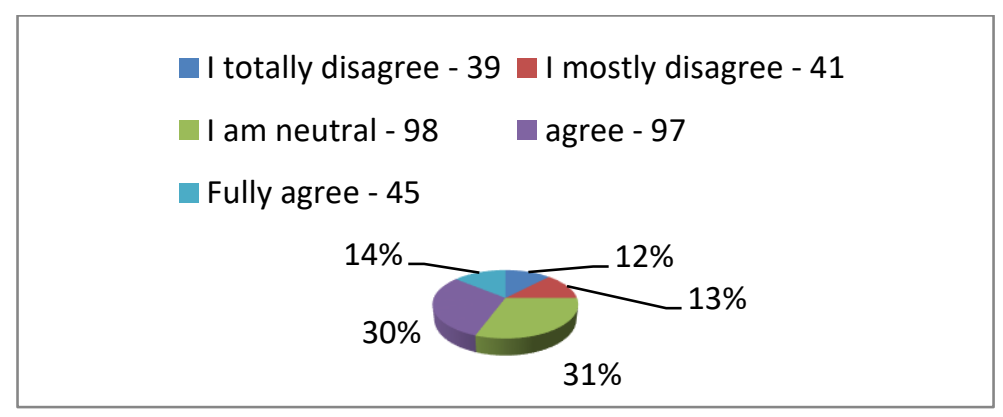

In the next question again, there is a slight fluctuation of attitudes with the fact that a significant percentage of respondents share the conviction that the ecological crisis debated in many local and global forums appear exaggerated. 
ISSN 2661-2666( Online) International Scientific Journal “Monte" DOI : 10.33807/monte.2.201908439 ISSN 2661-264X (Print)

\section{Nature is very fragile and vulnerable}

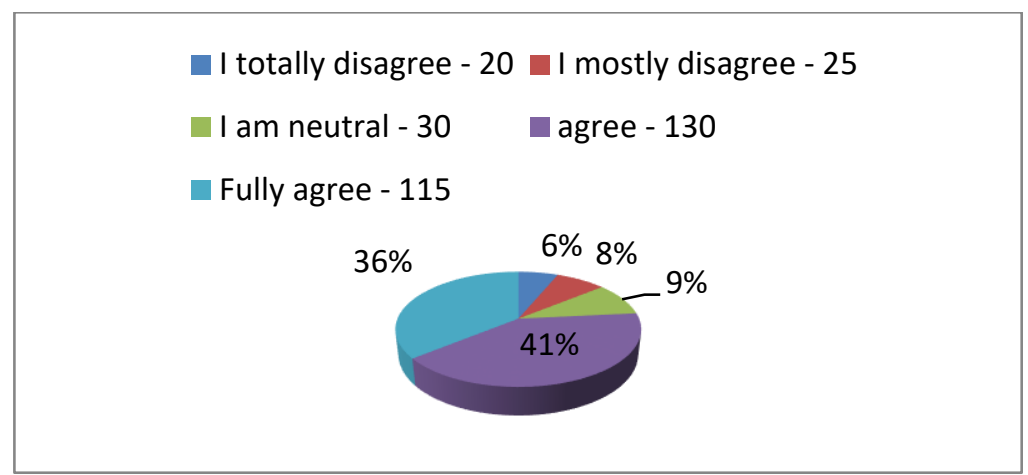

The next question is clearly noted the logical attitude of the respondents with the very fact that most of them (130 agree and 115 fully agree) agree with the fact that nature is however viable and vulnerable to the uncontrolled actions of the human factor.

\section{If we continue to do so with the environment, we will soon be faced with a great} ecological catastrophe

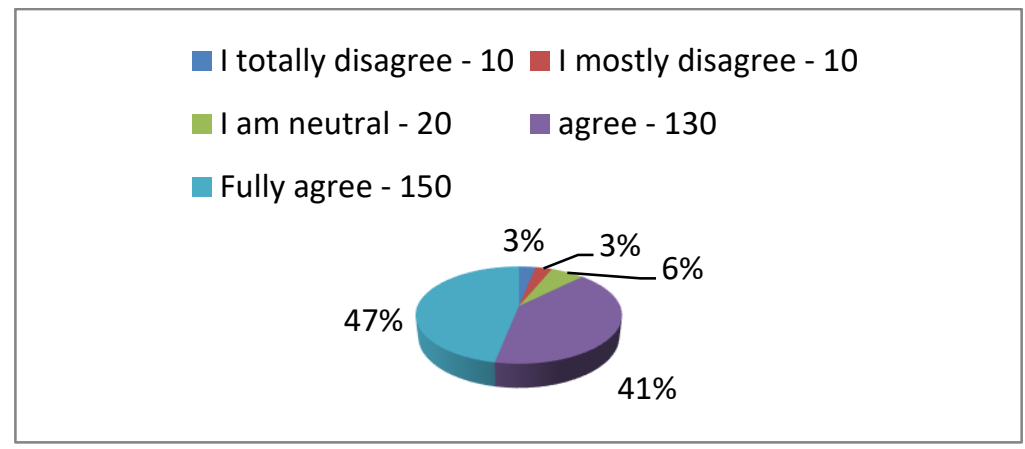

To the last question asked, the surveyed youths of the high schools in Tetovo have proved their full maturity with the very fact that they have rightly perceived that people can do everything but not to behave with irresponsibility to the nature surrounding them. They give clear messages to their answers if people behave with no responsibility to the living environment will soon be faced with consequences respectively with great ecological crises which will make the imbalance in the relation kind human - nature and from all that biggest loss will be human type. 
ISSN 2661-2666( Online) International Scientific Journal “Monte" DOI : 10.33807/monte.2.201908439 ISSN 2661-264X (Print)

\section{Conclusions and recommendations}

Based on the data obtained from the questionnaire we can conclude that the high school youth despite the elementary knowledge of the living environment, still, there is a need for additional activities in their schools explaining to them what are the capabilities of nature and resources that it has, what are the possibilities of nature in relation to the large number of residents living on Earth today, to be taught that nature and everything that exists is in harmony with one another and every touch in this harmony causes its disorder.

On the other hand, youth should understand that people should not rule the living things and everything else that exists on Earth but to coexist with them and cultivate them.

Regarding the "ecological crisis", youth should know that it is not exaggerated, but with it as an existent reality, we should be regarded as individuals, as social groups and as an organized society, beyond what is meant by the conclusions of numerous national and international organizations and institutions that deal with this issue.

Starting from these recommendations, the municipality of Tetovo should be more active with regard to the development of activities from this field by holding various environmental seminars, collaborating with non-governmental organizations for citizen sensitization about how important a clean environment is. Also unavoidable necessity represents cooperation with central and international institutions to attract investment in this field, not to bypass in any way particular segments that contribute to raising the awareness and culture of citizens about the living environment. 
ISSN 2661-2666( Online) International Scientific Journal “Monte" DOI : 10.33807/monte.2.201908439 ISSN 2661-264X (Print)

\section{Exploited Literature}

Ismaili, M., Durmishi, B., (2006), Shoqëria dhe menaxhimi I mbrojtjes së mjedisit, Tetovë

Kushtetuta e Republikës së Maqedonisë së Veriut, neni 43

Sluzben vesnik na R.S.M, Zakon za zdravstvena zastita, osnovni odredbi, clen 1

Sluzben vesnik na R.S.M, (2012), Zakon za kvalitet na ambientalniot vozduh, Skopje

Srbinovski, M., (2005), Environmental education, Prosvetno delo, Skopje

https://portalb.mk/222101-ndotja-e-ajrit-shkakton-vdekje-te-parakohshme/

https://www.slideshare.net/ervisicara/projekt-ndotja-e-mjedisit-ervis-cara 